IRSTI 112540

\author{
Gubaidullina M. ${ }^{1}$, Balaubaeva B. ${ }^{2}$, Karimova Sh. ${ }^{3}$ \\ ${ }^{1}$ Doctor of History, Professor of Department of International Relations, \\ Al-Farabi Kazakh National University, Kazakhstan, Almaty, e-mail: gubaidullinamara1@gmail.com \\ ${ }^{2}$ Candidate of Historical Sciences, Associate Professor of Department of International Relations, \\ Al-Farabi Kazakh National University, Kazakhstan, Almaty, e-mail: binurbalaubayeva@gmail.com \\ ${ }^{3}$ MA student of Department of International Relations, Al-Farabi Kazakh National University, \\ Kazakhstan, Almaty, e-mail: shiringu195@gmail.com
}

\title{
RENEWABLE ENERGY AND THE REGIONAL PROSPECT ON SUSTAINABLE DEVELOPMENT OF CENTRAL ASIA
}

In the conditions of increasing consumption of energy-related natural resources, the role of developing alternative energy sources rises as a factor in ensuring energy security is growing. Reducing the environmental burden on the environment is a contribution to the establishment of sustainable development. The energy resources that are traditionally used on a large scale by mankind - oil, natural gas, coal, are limited, can be exhausted before the year 2100. Lack of resources and uneven distribution among countries raises concerns about the future rational consumption and ways to replace energy dependence on fossil fuels. In this regard, much attention is paid to renewable energy sources, such as sun, wind, water, subsoil heat, biomass, etc. The use of renewable energy sources will help in solving the accumulated environmental problems, and along with them solve economic, social, political issues. The Central Asian region has a significant amount of natural resources, including oil and gas as the main sources of energy, which are the main export items of Kazakhstan and Turkmenistan, and water energy belongs to the subjects of the export dispute of Kyrgyzstan, Tajikistan and Uzbekistan. To maintain the stability and development of Central Asia, alternative ways of energy supply must be developed. In the region, the issue of the potential and conditions for the development of RES in the countries of Central Asia, the impact of the development of renewable energy sources on the future of the development of the region is relevant. The aim of this article is to determine the contribution of the renewable energy sources in the maintenance of sustainable regional development of the Central Asia with main stress on the UN Goal-7.

Key words: renewable energy sources, sustainable development (SD), hydro energy, wind energy, solar energy, biomass energy.

Губайдуммина М. ${ }^{1}$, Балаубаева Б. ${ }^{2}$, Каримова Ш. ${ }^{3}$

${ }^{1}$ тарих ғылымдарының докторы, профессор, әл-Фараби атындағы Қазақ ұлттық университетінің халықаралық қатынастар факультеті, Қазақстан, Алматы, e-mail: gubaidullinamara1@gmail.com

${ }^{2}$ тарих ғылымдарының кандидаты, доцент м.а., әл-Фараби атындағы Қазақ, ұлттық университетінің халықаралық қатынастар факультеті, Қазақстан, Алматы, e-mail: binurbalaubayeva@gmail.com ${ }^{3}$ магистрант, әл-Фараби атындағы Қазақ ұлттық университетінің

халықаралық қатынастар факультеті, Қазақстан, Алматы, e-mail: shiringul95@gmail.com

Жаңартыматын энергия көздері және

Орталық Азия тұрақты дамуының аймақтық перспективасы

Энергетикалық, табиғи ресурстардың барлық түрін тұтынуға байланысты баламалы энергия көздерін дамыту факторы ретінде энергетикалық қауіпсіздікті қамтамасыз ету, экологиялық жүктемені төмендету, қоршаған ортаға және салым белгілеудің тұрақты даму рөлі артады. Энергетикалық ресурстар әдетте, мыса^ы, мұнай, табиғи газ және көмір шектелген және тағы 2100 жылға дейін таусылуы мүмкін. Ресурстардың жетіспеушілігі елдер арасында әркелкі алаңдаушылық туғызып отыр, оған қатысты болашақ ұтымды тұтыну және құру тәсілдеріне деген энергетикалық тәуелділігін табиғи отынның қазбалы түрлерін көрсетеді. Осыған байланысты жаңартылатын энергия көздері, күн, жел, су, жылулық, жер қойнауын және биомассасына 
айтарлықтай көңіл бөлінеді. Жаңартылатын энергия көздері тек экологиялық мәселелерді ғана емес, әлеуметтік, саяси және экономикалық мәселелерді шешуі мүмкін. Орталық Азия бұл табиғи ресурстардың энергияның негізгі көздерін реттеу, мұнай және газ қоса а^ғанда маңызды мөлшерге ие болады, оларды экспортқа шығарады. Орталық Азия тұрақтылығын және дамуын ұстап тұру үшін энергия үнемдеудің балама жолдарын әзірлеу керек. Орта Азия елдерінде ВИЭ әлеуеті және даму шарттары туралы, сондай-ақ энергияның осындай жаңартылатын көздері аймақты дамытудағы әсері туралы сұрақ туады.

Түйін сөздер: энергияның жаңартылған көздері, тұрақты даму (SD), гидроэнергетика, жел энергиясы, күн энергиясы, биомасса энергиясы.

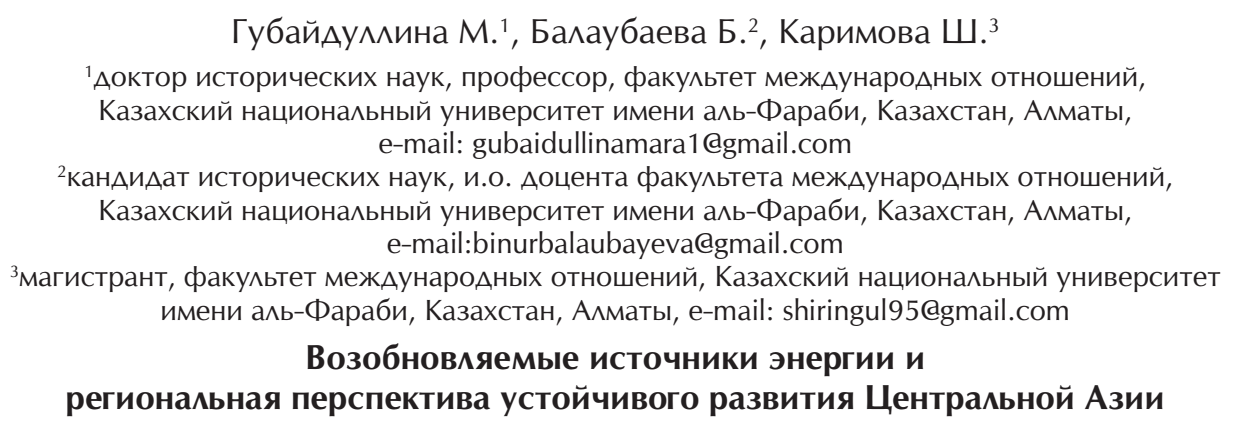

В условиях увеличивающегося потребления энергетических природных ресурсов возрастает роль развития альтернативных источников энергии как фактора обеспечения энергетической безопасности. Снижение экологической нагрузки на окружающую среду и является вклаАом в установление устойчивого развития. Энергетические ресурсы, которые в большом масштабе традиционно использует человечество, - нефть, природный газ, уголь, ограничены, могут быть исчерпаны еще до 2100 года. Недостаток ресурсов и неравномерное распределение между странами вызывают обеспокоенность в отношении будущего рационального их потребления и создания способов заменить энергетическую зависимость от природных ископаемых видов топлива. В этой связи значительное внимание уделяется возобновляемым источникам энергии, таким как солнце, ветер, вода, теплота недр, биомасса и др. Использование возобновляемых источников энергии поможет в решении накопившихся экологических проблем и, наряду с ними, решать экономические, социальные, политические вопросы. Регион Центральной Азии обладает значительным количеством природных ресурсов, включая несть и газ в качестве основных источников энергии, которые являются главными статьями экспорта Казахстана и Туркменистана, а водная энергетика относится к предметам экспортного спора Кыргызстана, ТаАжикистана и Узбекистана. Аля подлержания стабильности и развития Центральной Азии необходимо разработать альтернативные пути энергоснабжения. В регионе актуален вопрос о потенциале и условиях развития ВИЭ в странах Центральной Азии, о влиянии развития сферы возобновляемых источников энергии на будущее региона. Целью Аанной статьи является изучение необходимости перехода к возобновляемым источникам энергии для подАержания устойчивого регионального развития Центральной Азии, уАеляя основное внимание реализации сеАьмой цели ООН.

Ключевые слова: возобновляемые источники энергии, устойчивое развитие (SD), гидроэнергетика, энергия ветра, солнечная энергия, энергия биомассы.

\section{Introduction: the issue of renewable energy sources}

Sustainable development (SD) concept takes its early roots from the second half of the XX century when more and more scientists started to notice close relation between environment and social and economic development. The problems that resulted from the negative consequences of rapid human development, the psychology of mass consumption, population growth, economic industrialization, etc. were analyzed in the scientific research of the Club of Rome with his ideological and scientific leaderthe Italian economist Aurelio Peccei and members of the Club. They tried to draw the attention of the world community to the real and further evil threatening global future existence and development. Further promotion of the sustainable development concept was marked by publishing a scientific report "The Limits to Growth" where creation of the model of the world development from 1970 until 2100 year on the base of computer modeling was presented (Meadows and others, 1974). The authors of these models were American professor of Massachusetts 
Institute of Technology J. Forrester with further improvement of the models by the working groups of Dennis Meadows.

The modeling of global development trends included those components that have lied in the base of contemporary sustainable development concept. Their theory proclaimed that with the current tendencies of population growth, rise of post-war industrial production and, as a result, exponential increase of environmental pollution, land erosion, and decrease of amount of natural resources would lead to the global catastrophe. While working on concept of SD, they took into account the economy-political, social and environmental constitutes that were indivisible from each other and considered as one system where a human acted. While making the analysis components like population growth, industrialization, agriculture, and use of natural resources were taken into consideration (Медоуз, 2007: 342 ].

Contribution to the development of the concept was the next step - these decisions of the United Nations Conference in Stockholm. From conference 1972 was followed by Declaration on the Human Environment as one of the beginning parts of sustainable development policies (Report of the United Nations Conference on the Human Environment, 1972).

Though the conference was devoted to the mostly environmental problems, it was defined that surrounding environment was a result of human activity. And those environmental and ecological problems had to be solved by solving simultaneously the problems caused by people. The president of this conference Maurice Strong defined the term ecological development (ecodevelopment) as such socio-economic development that would take into account environmental constitutes. With this end, the Declaration promoted 26 principles according to which people should treat the environment in such way that in future to enjoy the same possibilities. As a main result of the Conference the new specialized agency of the United Nations occurred that was called UN Environmental Program. The Program was created with the aim for protection and improvement of environment for present and future generations. In 1980, the International Union for Conservation of Nature and Natural Resources (which was established in 1948 with aim to inform global community about biodiversity conservation problems) published a World Conservation Strategy that was fundamental in introduction to the phrase of sustainable development (World Conservation Strategy, 1980: 14-15).
The strategy is proclaimed as the system of methods to rationally manage biosphere's available natural resources in such way that the nature could reproduce its capacities to supply future generations as well. Finally, the general concept and definition of sustainable development that the global community has accepted and uses nowadays was, firstly announced in 1987 in a report of the World Commission on Environment and Development in the General Assembly 42 ${ }^{\text {nd }}$ session. The head of this Commission Mrs. Brundtland argued that environment and development are the definitions that cannot be considered separately. Many natural resources can be destroyed by those forms of development that need exactly these resources. The contradiction of the concept was that development, economical in particular, was mainly possible by consuming a large amount of natural resources. This fact was in large extent controversial because of undefined development-consumption correlation. It was concluded in the definition of sustainable development on Brundtland Commission that characterizes the concept: development that meets the needs of the present without compromising the ability of future generations to meet their own needs (Report of the World Commission on Environment and Development, 1987:41).

The new step of the systematization and structuring sustainable development concept, and the formulation of sustainable development principles, was the Conference in Rio-de-Janeiro on Environment and Development on June 3-14, 1992. Important, the principle 25 of the Declaration of the Rio Conference it is officially underlined that "world, development and environment protection are interdependent and indivisible" (Rio Declaration on Environment and Development, 1992). The Conference was based on the fact that industrial development has been the main ground of economic development and rise of socio-economic life of society. However, it doesn't properly take into account resource scarcity and natural capacity. In this regard, questions in focus were production and consumption systems in industrial world, demographic booms, population growth, increasing gap between rich and poor, ecological catastrophes and climate change. Nevertheless, the sustainable development concept Rio was widely approved by global community underlying importance of its implementation. For the first time there was adopted an action plan for the upcoming century called Agenda 21 (Agenda 21, 1992).

Also, the Agenda 21 and the Rio-de-Janeiro Declaration on Environment and Development the formulation of 3 core elements as a base of sustain- 
able development: economic growth, social development and environmental protection. However, despite its immense contribution in world's consciousness about further development, the Rio Conference was mostly declarative.

The United Nations summit in a new millennium which took place on September 8, 2000 set a concrete range of goals until 2015. The Millennium Declaration was important in sustainable development maintenance because of the fact that for the first time all the member-states accepted the concrete goals for struggle against poorness, starvation, illiteracy, diseases, environmental degradation, and women discrimination.

The rational consumption is related to energy on which this work is mostly accented. Development is impossible without energy. People are now too dependent on the electricity; almost every machine needs fuel to work, and mostly energy is taken from natural resources. In this regard a goal-7 is devoted to affordable and clean energy. Energy is a core power in development of all countries, and in this regard the 2014-2024 are proclaimed by the UN as years of sustainable energy for all in order to provide common access to energy. Since conventional energy resources are limited, plus they make more hazardous effect on environment, the alternative energy resources are needed which ought to be renewable and clean.

The wide-spread development and transition to renewable energy sources in many developed countries represent a good example for the Central Asian countries. From the end of 2015 year, majority of countries in all regions around the globe have formed their politics toward support and development of renewable energy. According to the IRENA Renewable Capacity Statistics 2017, among top countries with highest RE total capacity are China, the United States, Brazil, Germany, Canada, Japan, and some others (IRENA, 2017). The implementation of RES in the region is especially relevant since the energy security constitutes one of the crucial aspects in international relations of Central Asian states. In a whole the region has significant reserves of natural fossil fuel resources, however their unequal distribution among the countries and inefficient energy management create threats to development of the whole Central Asia.

The slogan of exhibition Astana EXPO - 2017 was the Future Energy. This theme highlights the importance of global tendency on transition to more ecological clean, safe and sustainable energy with realization of world targets of sustainable development goals.

\section{Some theoretical approaches in substan- tiating the concept and goals of sustainable development}

There are different explanations and descriptions of sustainable development and it is because this concept refers to many fields of research, that is, it is matching to any scientific discipline, be it economics or ecology. Thus, every scholar tries to define the term from the prospect of his/her own interests. However, combining different theories and approaches from specialists of different fields of studies, it is possible to view the concept in a coherent and comprehensive sight.

The German scientist and one of the leading specialists of systems theories Hartmut Bossel explores systems of SD showing for local levels. In the book "Indicators for Sustainable Development: Theory, Methods, Applications" he says that there can't be a universal approach to every region because the concept of SD includes all the spheres of human beings and problems are not equally distributed in all regions. For example, in one country there can be a harsh problem with hunger, in another - pollution. Therefore, for every separate region (it can be as among as well as within countries) there should be a group of independent representatives of different social groups, professions and scientific schools to define a set of showing for concrete region. Bossel marks out that to evaluate sustainability of development is possible with such indicators that include all aspects of system's living capacity; however it has to be compact at the same time. He underlines that a society that is just and fairly ruled is much more "securely sustainable than a materially sustainable brutal dictatorship" (Bossel:3). Bossel combines SD indicators in several subsystems:

- Subsystem of individual development to where he includes civil rights and freedoms, prosperity level, health, education, recreation and art, gender roles and others;

- Social subsystem which consists of population dynamics, its socio-demographic and social classes structures, ethnic components, social security and others;

- Political governance subsystem includes political structure, policy in spheres of taxes, laws, human rights, demography, international and others;

- Subsystem of infrastructure to which relate cities and other settlements, transport, food and other provisions, goods and services, information, science and others;

- Economic subsystem includes production, finances, market, entrepreneurship and labor and others; 
- Subsystem of environmental resources that consists of ecosystem, biodiversity, level of pollution, natural resources and their limitation and regeneration (Bossel:17).

Also these subsystems compose three major systems which lie in contemporary SD concept. They are social system (including subsystems of individual development, social and political governance); system of provision (subsystems of infrastructure and economy), and ecological system (environmental subsystem).

American ecology economist Herman Daly presented the concept of steady-state economy (Daly, 1973). He notes that to develop steady-state society is necessary and it's defined not by limits of natural resources but by limits of allowed amount of environmental pollution.

A American scientific research Worldwatch Institute, that was founded in 1974 by Lester Brown, was aimed to solving similar problems as the Club of Rome. In the book "Building a sustainable society" (1981) Lester Brown considers all the problems that humanity is facing today. Brown predicts the same destiny for modern civilizations that happened to the Mayas many centuries ago if people don't stop their "business as usual". The Mayan civilization disappeared by assumed reasons of deforestation, land erosion that led to famine because nature capacities were not enough for growing population (Brown 1981:4). He stresses that people need to take actions to prevent consequences rather than cure them afterwards. Lester Brown says that renewable energy will help to develop economic activities in much broader requested in wide extent. He was quite optimistic that time supposing that these changes and transition towards economically and environmentally profitable renewable energy would happen within few decades.

The famous Columbia University's professor of economics and sustainable development Jeffrey Sachs defines two aspects of sustainable development. The first lies in understanding of how economic, social, political, environmental, and cultural factors interact together in the world dynamic. The second aspect of the issue is practical: setting, implementing and achieving goals towards prosperous, clean, environmentally sustainable, fair world with developed economies that don't overrun physical capacities of the planet. Sachs marks out four dimensions of SD, adding also political dimension to social, economic and natural-environmental ones. He underlines that good governance that is fair, just, and careful of citizens, with established normative base can contribute to happy and satisfied society.
Jeffrey Sachs is expresses his concerns more and more about hazardous impacts of industrial productions on environment and human health. In his article named "Sustainable Development Economics", he suggests that governments have to review their policies towards investments by establishing a long-term strategy. Governments must know how to strengthen sustainability of environment by using less or zero CO2-energy. Thus, investments are to be flown towards smart infrastructure, towards railways, ports and energy sector (Sachs 2014:15).

A Russian scientist in social ecology, security and sustainable development, globalization, and other natural sciences A.D. Ursul notes that sustainability of biosphere and its ecosystems it is an ability to keep up its functionality and capacity to realize further evolutionary processes and restore after any breaches and negative influences (Урсул 2013:23). It is provided due to vast biodiversity, to which a separate goal in SDGs is devoted. Consumption decrease to a normal level of physiological needs will shorten usage of natural and mineral resources, decrease developed countries dependence on raw materials import and thus global tension on resources possession will be diminished. This is how one of the ways of one of the problems solution is seen.

Kazakhstani scientist Bela Syrlybayeva in her article "Sustainable Development: the Problems of Definition and Realization" notes that problems of humanity appear because of overconsumption (Сырлыбаева 2014: 6). For the Central Asian countries to develop science intensive spheres is especially crucial moment. The region economy is mostly based on natural fossil resources which is unstable in the prospective of SD. In this regard, to promote SD in the region it is reasonable to invest in scientific base, in modern information and technological space creation.

The case of international legal regulation of environmental protection and global cooperation towards sustainable development was considered by M. Gubaidullina and A.Kargina. She also highlights global initiatives of the Republic of Kazakhstan as contributive measures for sustainable development achievement, and considers the fundamental principles of sustainable development from the view of triune concept: energy-economy-ecology, and suggests the ways for realization of its balance (Gubaidullina, 2015: 47-80).

For the Central Asian countries to develop science intensive spheres is especially crucial moment. The region economy is mostly based on natural fossil resources which is unstable in the prospective of 
SD. In this regard, to promote SD in the region it is reasonable to invest in scientific base, in modern information and technological space creation. Thus, reviewing works of different scholars from different specialized spheres of research a next conclusion can be made. Sustainable development by all of them is still considered through the prism of triple dimension and despite various prognosis and forecasts they underline that with smart coordination of all three constituencies (social, economic and ecological), the sustainable development concept might have its future. In this regard, the concept of sustainable development is being one of the prior concerns of global community.

\section{Task Force for promoting renewable energy}

In 2000, there was organized a Summit of the G8 group in Okinawa, Japan, where it was decided to form a Task Force for promoting renewable energy and helping developing countries in usage of this kind of energy. In the first report of the G8 Task Force about renewable energy it was noted that more developed countries are recommended to promote RE with intensive efforts first of all in their own territories. So doing would lessen the costs in RES use and as a consequence make it easier for less developed countries to afford enjoying renewable on their selves. Two years after the millennium summit, in 2002, the high-level meeting took place in Johannesburg, South Africa. The summit didn't contribute significant changes in the concept of SD, but it was important from the perspective of actions.

Another initiative that contributed globally to promotion of RE was the decision of the German government to create an international agency that was to overview tendencies in developing sustainable, clean and affordable energy through using renewable sources. This initiative was widely supported by other countries thus making it the intergovernmental organization comprising nowadays 150 countries (including Kazakhstan and Tajikistan from Central Asia) and 28 more to become members (among them are also Uzbekistan and Kyrgyzstan).

At the Johannesburg conference the social and economic questions were considered at the same level as environmental problems. It was announced that the environmental degradation had become even sharper because of uneven development and poorness. The executive director of the UNEP Klaus Topfer put forward the task to make environment for development.

In the Declaration on sustainable development and action plan adopted at the Johannesburg conference a human was put in central position and such questions as poverty reduction, health and sanitation improvement, clean water provision were considered widely to maintain prosperous and sustainable life (Johannesburg Declaration on Sustainable Development 2002). We should mention some progress in the development of the concept of SD at the conference Rio +20 , which took place ten years after Rio in June 2012. First of all, the decision to start planning sustainable development goals after 2015 was adopted.

Another progress was that the document contains the chapter devoted to "green economy". The conference participants agreed that such economy in the context of sustainable development and poverty eradication was one of the most important instruments of SD maintenance. As is known, the New Agenda, adopted on the anniversary $70^{\text {th }}$ session of the United Nations 2015, was proclaimed with the name of Sustainable Development Goals (SDG). They are the vision of the United Nations until 2030 when the 17 goals are to be achieved (2015:3-4, 2123).

The SDG concept is based on the five "P" orientations. They include people as the main targetgroup the development is devoted to; our planet as the main habitat of all living things; development is obviously aimed for prosperity that will lead to peace which can be gained through partnership. The UN Ex-Secretary General Ban Ki-moon adopted a global initiative Sustainable Energy for all and declared a ten years until 2024 as Decade of Sustainable Energy.

Having explored the evolution and main idea of sustainable development concept, the conclusion can be made that SD strategy is aimed to harmonize human relations between each other and what is more important - between humans and nature. However, the world is too complicated and it would be so naïve to think that we can create a one formula following which we will achieve all the goals we have set. No, the sustainable development is exactly that science that has to create immense amount of ways towards global problem solutions and to be resilient and flexible to any changes in the system and to invent new ways if others are not effective.

In the beginning of the XXI century the world leaders agreed to set comprehensive goals named Millennium Development Goals that were consequently transformed into Sustainable Development Goals. So, consider the following global goals and objectives, which have become a guide to the action of many countries. The strategy of sustainable development goals is directed on the achievement of a welfare world through poverty, hunger and gender inequality eradication, rational consumption of 
existing natural resources, biosphere systems preservation, and national legal base transformation for the common contribution into effective implementation of the goals. Despite the amount of the goals are 17, they are interconnected within the three core elements: economy, ecology, and society.

The second target is achieved through thorough examination of strategic energy resources distribution among the countries in the world. For example, Central Asia is considered to be one of the richest regions in the view of resource sufficiency. At the same time, the problem is hidden in the uneven provision of strategic energy sources between the nations. Thus Kazakhstan, Uzbekistan and Turkmenistan have abundant fossil fuels, whereas Kyrgyzstan and Tajikistan are rich in water resources that constitute main source of energy.

According to the research, attention is directed to the following benefits of using renewable energy sources. This kind of energy sources has crucial importance for climate change mitigation. The next problem the renewable energy sources solve is electricity access provision. Exploiting RES, such remote regions that are not connected to the central grid system can be provided with electricity. It is especially relevant in the conditions of Central Asian countries suffer from electricity deficit.

The advantage of renewable is creation working places, the 8.1 million people in wider or lesser extent have been employed so far in the sector of renewable energy. The RES implementation will decrease consumption of finite organic fuels and soften the man-caused pressures of human activity to environment. In this regard, renewable are of important contributors to clean "green" and sustainable development. In the regional policy of Central Asia, it is important for states to take into account and adopt the best world practices. The core element in this case is the smart regulatory policy with accurate legal base. It includes affordable tariffs, tax releases, and privileges in the consumption of renewable energy sources. The foreign experience is determined by progresses in technical, technological, informational, and scientific spheres that promote better utilization of the RES.

\section{Potential of renewable energy development in the Central Asian region}

The region has very favorable conditions to develop of energetic sphere in Central Asia, has the potential for renewable energy sources utilization. The following non-conventional energy sources have been defined as the most favorable for CA:
- Solar energy, essential feature of which is sufficient availability in all five countries, first of all, the most favorable conditions in Tajikistan, Turkmenistan and Uzbekistan;

- Wind energy which is more profitable to develop in Kazakhstan, good wind potential have Turkmenistan and Kyrgyzstan as well;

- Water energy is used in Tajikistan and Kyrgyzstan; however they use conventional hydro plants. For utilization small hydro plants Kazakhstan has necessary resources;

- Biomass energy is least developed energy source in the region, though it has its good place for implementation in Kyrgyz energy sphere.

Potential of the RES has the region, but from the regulatory point of view, all countries lack efficient legal base for comprehensive promotion of RES utilization. Nevertheless, a significant progress has been noticed in Kazakhstan, Uzbekistan and Tajikistan by improving national laws and strategies.

As the every other phenomenon, the renewable energy sources have own disadvantages. For the widespread use of RES, there are a number of the following obstacles: Dependence on weather and climatic conditions, that for solar and wind power plants is the main obstacle. The construction of installations for renewable energy production cause initial hazard to environment. In order to increase power generation capacity, the technologies power plants working from renewable energy sources demand higher costs thus making this kind of sources less affordable, especially for lower income countries. Despite that renewable energy sources utilization is viewed in long-term prospects, they are becoming of crucial importance in regional development today, because the they will contribute to sustainable development in the region.

Central Asian has a big potential to develop renewable energy as there are all necessary conditions for its implementation. Natural renewable resources throughout the whole region are diverse and a separate country has its own peculiarities in the direction of RE development. Thus some countries can rely on solar, others on wind and another on hydro powers.

Central Asian countries: the path to renewable energy

\section{Kazakhstan: EXPO-2017 "Energy of Fu- ture".}

Kazakhstan plays a big role in promotion of the development of ecological clean, safe and sustainable energy sphere making accent on the renewables. However, RE in the country hadn't been so well developed, since there was no necessity because of the 
abundant reserves of mineral resources. The biggest part of energy production came from fossil fuels and economic development was in priority, i.e. it was above ecological and social factors. Nevertheless, recent global trends and promotion of RE effectiveness and transition towards its wide implementation coincided with Kazakhstan's devotions for sustainable development.

According to the law of the Republic of Kazakhstan "On support for using renewable energy sources" from July 4, 2009, the definition for RES is following: "it is the energy sources that are constantly renewed due to natural processes and they include next types: solar radiation energy, wind power, hydrodynamic water energy, geothermal energy: ground warmth, ground waters, rivers, reservoirs, as well as anthropogenic sources of primary energy resources: biomass, biogas and other fuel from organic wastes used for electric and/or thermal energy" (Закон Республики Казахстан, 2009: статья 1:1).

Energy potential from the RES is very high in Kazakhstan; however, the share in total energy consumption is miserably small. According to the BP Statistical Review of World Energy from June 2016, renewable energy sources in Kazakhstan shared less than $0.05 \%$ from world's total in 2015 (BP Statistical Review of World Energy 2016). The western region of Kazakhstan doesn't have connection to the common energy system of the republic and is supplied by the electric energy from the common energy system of Russia. In energy economy of Kazakhstan there is a high level of deterioration of equipment that reaches 70\% (Nadirov, 2014:80-85). With the utilization of renewable energy sources it will be possible to provide with power remote and hard-achieving regions thus reducing energy deficit.

Kazakhstan has favorable climate conditions for developing and consumption solar energy on the two thirds of the whole territory. In the southern parts of the country solar radiation reaches 2-3 thousand hours per year and its power on the horizontal surface is equivalent $1280-1870 \mathrm{KWh}$ on a square meter per year. This makes the introduction of new technologies possible in all regions. Developing such energy is not just ecological important, but also it contains economic benefits.

On the territory of Kazakhstan there are huge resources of wind power and it is considered to be the most favorable and energy effective sources of RES. The most important wind resources are located in the region of the Jungar Gates the power of which can reach $17000 \mathrm{kWh}$ on a square meter. Other prospective regions are Akmola region, the Caspian Sea coast, Zhambyl region, and others. Shelek corridor located between mountain Zaili Alatau and Zhetysu ranges also has a good wind potential with the average annual speed of $7.8 \mathrm{~m} / \mathrm{s}$ on the $50 \mathrm{~m}$ height. The wind power density is about $510 \mathrm{~W}$ per each square meter that makes possible to generate approximately $3200 \mathrm{kWh}$ of electricity (Дорошин, 2006:8].

The country has big reserves of small rivers energy sources that content 2 billion $\mathrm{kWh}$. The total potential of hydro resources can be 170 billion $\mathrm{kWh}$, of which 23.5 billion $\mathrm{kWh}$ might be effectively used in economy. Main water resources are located in Eastern and South-Eastern Kazakhstan. The Southern region the total potential of this kind of energy sources is equaled 10 billion $\mathrm{kWh}$. In the northern and central parts of the republic there are not so many hydro resources.

The production of electric energy from the RES in Kazakhstan increased on 22\% in 2015 in comparison with the year before, and in 2016 the share of renewable energy resources approached $1 \%$ in total volume of electric generation. In the beginning of 2016 year there were 48 enterprises of the RES with sum capacity $251.55 \mathrm{MW}$. Along this, there were completed 14 projects on renewable energy implementation with total capacity of $119,9 \mathrm{MW}$ and by 2015 there were 26 realized projects. Among them are solar power plant Burnoye which is set up in the Zhambyl region and its capacity reached $50 \mathrm{MW}$, Yereimentau wind power plant (45MW) in the Akmola region, Upper Baskan hydropower plant in the Almaty region with a capacity of $4.2 \mathrm{MW}$, Ryszhan hydropower plant in the South Kazakhstan region with a capacity of $2 \mathrm{MW}$, as well as expansion of wind power station Vista International in Zhambyl region until $21 \mathrm{MW}$ (increase on $12 \mathrm{MW}$ ) (Information-Analytical Magazine Kazenergy 2016:49).

The geothermal resources also have their place in RE development on the territory of Kazakhstan, in the Almaty, Jarkent, and Arys artesian basins. As Kazakhstan is a big producer of cereal crops, it is also possible to get energy for electricity and heating from burning stems biomass of which reaches more than 3 million tons annually (Обзор ЮHECKO - 2010: 65).

Kazakhstan tries making alternative energy sources more widely used in the country that is determined by green development and international experience. According to President Nazarbayev's ambitious 2050 Strategy, Kazakhstan will use renewable and alternative energy sources to create $50 \%$ of the electric capacity generated in Kazakhstan.

The country plays an important role in promoting sustainable development ideas. There are worked out the National Conception on transition to Green 
economy and correlated initiative of "green bridge" which is aimed unite countries in this direction; "Global energy-ecological strategy of sustainable development in XXI", national programs directed on ensuring sustainable development in key sectors, such as: energy, water, municipal and agriculture, industry, and biodiversity. These initiatives were proposed on the summit "Rio +20 " in 2012. A chosen theme on EXPO-2017 - Energy of Future - has a global significance. By the Kazakhstan's Strategic Development Plan until 2020 year the country is to achieve the part of renewable energy sources up to 3\% (Strategic Development Plan of the Republic of Kazakhstan until 2020 year, 2010). In 2015, at the UN General Assembly's anniversary session, Kazakhstan declared an initiative to create an International centre to develop "green" technologies and investments.

In order to better develop the RES, some changes to the Law on renewable energy sources were made in 2013. The new legal act is directed for support of investors as well as consumers. In particular, introduction of fixed tariffs allows guaranteeing investors for the reimbursements; this makes investments attraction more favorable. By the law, the electric power from the RES is to be distributed among all consumers through specialized centre of renewable energy support.

From the February $24^{\text {th }}, 2017$ there was admitted a Plan for placing facilities for the use of renewable energy resources throughout the territory of Kazakhstan with the southern part leading in amount of RES installations. According to this plan, there are 69 installations of solar, wind and hydro electric plants. The majority of the plants are hydro energy stations, but the summary installed power of established solar plants is the biggest equaling 814.9 MW, whereas this of hydroelectric power station equals $359.9 \mathrm{MW}$. The total installed capacity of all the RES using objects is about $1910 \mathrm{MW}$ (Об утверждении Плана размещения объектов.., 2017). According to the action plan on alternative and renewable energy development in Kazakhstan for 2013-2020 years, it is planned to exploit $106 \mathrm{ob}-$ jects of RES with total capacity of 3054.55 MW (Об утверждении Плана мероприятий.., 2013).

Kazakhstan is a member of all UN conventions on environment. Thus, in the end of 2016 Kazakhstan ratified the international Agreement on Climate Change that was figured out during the Conference on Climate in Paris, 2015. According to the statements identified in the agreement, Kazakhstan is obliged to shorten on $15 \%$ greenhouse gas emissions until 2030 that will be possible with smart and consecutive regulation measures. For the Republic of Kazakhstan the RE development is also necessary to solve the problem of electricity provision for regions where electric grids are hard achievable.

\section{Development potential of RES in Kyrgyzstan.}

Since the Kyrgyz Republic doesn't possess fossil fuels for energy generation, the main sources for energy supply are waters. According to the Kyrgyz Ministry of Energy, annual energy production that flows from hydro powers is estimated at about $94 \%$. Electric energy system of the republic is not able to provide sustainable energy supply throughout the year. Most of the energy consumption is during the winter periods. In the warm seasons the overall energy consumption is about 23 million KWh per day, whereas during the heating periods it reaches more than 70 million KWh. As a result, power generators and transmitters don't work in full strength in summer times and are loaded only by two thirds of their capacities. The solution of many energy problems in the country can be found in renewable energy sector development. Nowadays, the total potential of RES in Kyrgyzstan is estimated at 840 million tones of conditional fuel. Notwithstanding, the real RES consumption is only $0.17 \%$ of this potential. Renewable energy sources can contribute into reliable and sustainable energy supply for remote rural areas and thus correct poverty problems (Kazakhstan and Kyrgyzstan..,1997).

The legal regulations lack methodology of tariffs calculation, of mechanisms for setting up and selling electricity. In this regard, in order to coincide with the models of sustainable development, there should be diversification of resources for energy production. With this end, the solar energy utilization is among the ways of this problem solution. There are 260 sunny days in Kyrgyz Republic, making it beneficial to develop solar energy sphere. Thus it is reasonable and favorable to set up local separate systems of the RES that don't need to be connected to the existing electric nets.

\section{Potential of RES in Uzbekistan.}

Uzbekistan is a country with the highest population in Central Asia and relatively developed, has good possibilities to develop energy sector from RES. Taking into account the high advancing rates of development of the industrial sector, the country's electricity needs in 2030 will increase by about 2 times against the 2013 year and will amount to over 105 billion $\mathrm{kWh}$.

The gross potential of renewables in the country is estimated at 51 billion tons of fuel equivalent; even though the technical potential is many times 
less than gross potential being around 182.3 million that exceeds annual volume of conventional energy resources in three times. The most profitable and reasonable spheres to develop in the RE sector are hydropower and solar energy. Uzbekistan takes efforts to solve electricity deficit problems by developing own hydro energy potential.

A field of utilization the water resources for energy in Uzbekistan has been explored quite well in comparison with the other sources. The gross potential of the big and small rivers is counted at 9.2 million tons of oil equivalent, with technical prospective of 2.32 million tons of oil equivalent. The government adopted a new program for hydro power sector development on the term of 2016-2020. In the frames of this program about 890 million USD dollars of state money and loans will be directed to modernization of hydro power stations to upgrade the power capacity until 1384.99 in total and for the construction of new plants in total capacity of 94.4 MW (O программе развития гидроэнергетики на 2016-2020, 2015: 77].

Sun potential in Uzbekistan has prior perspectives because the gross potential of solar power is approximately 50900 million tons of oil equivalent, which is $99.7 \%$ of all explored RES in the country. The sun period on the territory of Uzbekistan reaches 2000 hours in the north and about 3000 hours in the south, this is equal to solar radiation of 4800 mega joules per square meter and 6500 mega joules per square meter, respectively (O программе развития гидроэнергетики, 2015:77-81].

The most favorable regions are north-western part, in particular Usturt plateau, and Bukhara, Navoi, Kashkadarya and Tashkent regions. Improvement in knowledge basis and technological development allow making progress in the field of RES. Wind energy development is favorable for rural economy in some remote regions. Many farmers and inhabitants of such villages can benefit from the plants installations because additional possibilities for energy supply and therefore better irrigation positively influence on their prosperity.

4. Perspective energy source for Tajikistan.

In Tajikistan energy sector is also one of the main fields of economy, however the energy deficit concludes about 5 billion KWh per year. There is about $70 \%$ of population living in rural area with access only to $8.58 \%$ of electricity; in particular, there are a million of people who suffer from electric energy deficit. Main and perspective energy source for Tajikistan is hydro energy that is the cheapest in relation of production. However, other natural clean resources like sun, biomass, wind, and geothermal energy can supply almost all energy needs of the country.

Evaluating the volume of hydro power resources Tajikistan is the leader among the Central Asian states. It is potentially possible to generate more than 527 billion KWh annually. However, consumption of the economic hydro energy potential is stated at less than 4 per cent. Especially favorable conditions exist in mountainous regions that occupy about 93\% of the entire territory. To comprehensively develop small and mini HPPs the country needs modern proper technologies, improvement of industrial base, and increase the know-how of specialists.

A potential source of energy in Tajikistan may be agricultural waste - biogas from manure and bird droppings. At present, several experimental generators working on biogas are in operation. In addition, it is possible to generate energy from household waste.

The climate of Tajikistan is favorable for the use of solar energy. There are 280-330 sunny days per year in the country. During the year, the intensity of solar radiation varies from 280 to $925 \mathrm{MJ}$ per square meter in the foothills and from 360 to $1.120 \mathrm{MJ}$ per square meter in the highlands. Solar energy can potentially provide $10-20 \%$ of the energy demand (Обзор ЮНЕСКО - 2010: 62-64).

Wind energy potential in Tajikistan is low, but in a number of regions its use could become an additional source of energy (in addition to hydropower). The strongest winds are observed in the mountains (on Fedchenko Glacier and Anzob Pass), where the relief affects the convergence of air masses (for example, in Khujand and Faizabad). In agricultural regions it is possible to use biomass for thermal and electric power production. According to experts, biomass utilization has a practical meaning in households of $75 \%$ of the country's population. Big cattle farms and in agriculture it is profitable to use biogas installations. In the country there are some biogas generators that are used for local needs.

5. Potential of renewable sources of Turkmenistan

Turkmenistan is too dependent on its gas export that creates energy insecurity for the country. By now, when the country is confident in the mineral resources reserves, the development of alternative energy sources doesn't present serious concerns. However, Turkmenistan as a member of different international conventions on climate and environment issues, implements its obligations in the form of own laws and decrees. Though there are no separate laws about renewable energy sources, some provisions of RES utilization exist in the frames of 
the Law of Turkmenistan on Electrical Energy from August 16, 2014 (Закон Туркменистана об электроэнергетике, 2014: article 10 (4).

The country stresses its accent more on environmental problems, climate change in particular. Thus, there is a National Strategy on Climate Change adopted in 2012; an initiative proclaimed by Turkmen delegation during the $66^{\text {th }} \mathrm{GA}$ session to create a Regional Centre on Climate Change problems solution. To develop renewable energy sector the country still lacks proper legal base, though Turkmenistan has favorable conditions to use RES in its energy sector. As the most favorable alternative energy resources in Turkmenistan are seen the energy of sun and wind. The wind power generation is potentially possible to develop in mainly western and northwestern regions, whereas solar energy is accessible on the entire territory of the country. About $4 / 5$ of the territory consists of deserts and mountains where live about $10 \%$ of population. For every small rural household it is unreasonable to provide them with separate gas pipelines or electricity grids. For this reason, the inhabitants of those regions transport fuels for the diesel generation installations that supply them with energy. However, this kind of energy provision is not sustainable since transportation depends on weather and terrain conditions.

The natural and climatic conditions of Turkmenistan are exceptionally favorable for the wide use of alternative energy sources, such as solar, wind, geothermal and biomass energy, in the production of electricity, biofuels, heat and cold. Turkmenistan has a lot of sun and wind resources, it is profitable to develop solar and wind energy generation. With the existing efficiency of solar photovoltaic cells and the average annual intensity of solar radiation, which is 600 watts per square meter, all the electricity produced by Turkmenistan's power plants during the year which is about 14 billion $\mathrm{kWh}$ can be obtained from one solar photovoltaic station with active area of several dozen square kilometers.

With effective use of this energy, it is possible to provide up to $25 \%$ of heat consumption in heating systems, up to $50 \%$ in hot water systems and up to $75 \%$ in air conditioning systems; it allows reducing consumption of organic fuel and save 2364 thousand tons of fuel and energy resources or $52.6 \%$ (Pendzhiev, 2015:14-24). The second most prospective RES in Turkmenistan is wind power. Favorable regions for wind energy generation are Balkan oblast near the Caspian Sea.

There is a state Concept on development of electric energy sphere of Turkmenistan on 2013-2020 years (Национальная стратегия Туркменистана, 2012). It includes following measures for produce energy on the base of renewable energy sources use: further support for research and development of renewable and alternative energy technologies, as well as their adaptation to the climatic conditions of Turkmenistan; the introduction of small and medium-sized installations of renewable and alternative energy in remote and sparsely populated areas; the introduction of own production capacities and the increase in the share of renewable energy in the country's energy balance; creation of economic incentives for the use of alternative energy sources.

\section{Conclusion}

The energy sector of the Central Asian countries is one of the important questions in the regional and international cooperation. Combining the separate analysis of the countries in Central Asia, the common picture is looked as following. Priority direction of RES in Kazakhstan relies on wind energy; small hydro power plants and biomass energy is favorable for Kyrgyzstan; for Turkmenistan the main accent is made for solar power plants; Uzbekistan's most beneficial field in RE as well as in Tajikistan are solar and small water power plants energy. From the economic point of view, if taking into account short-term prospective, the RE will not be as much favorable for countries whose economy is based on natural mineral resources. It is explained by lower prices for conventional energy production rather than development and exploitation of new technologies for RE.

Central Asia at a whole has immense potential to develop renewable energy sector thus providing diversification in energy sector and meet countries' needs in energy minimizing imports and increasing energy security in the region. The most rapid development in the field of renewable energy is noticed in Kazakhstan and the least developed sphere of RES is in Turkmenistan.

The wide-spread development and transition to renewable energy sources in many developed countries represent a good example for the Central Asian countries.

The implementation of RES in the region is especially relevant since the energy security constitutes one of the crucial aspects in international relations of Central Asian states. In a whole the region has significant reserves of natural fossil fuel resources, however their unequal distribution among the countries and inefficient energy management 
create threats to development of the whole Central Asia. The UN Secretary-General Ban Ki Moon expressed a phrase during the march against climate change that became a crucial promotion for actions. It is said: "There is no Plan B" because we do not have a "Planet B." (Ban Ki Moon 2014). Significant step 2015 was the UN General Assembly's adoption of a SDG where goal seven (7) is dedicated to the sustainable energy for all.

From the geopolitical, geo-economic and regional point of view, renewable energy can solve such problems as import dependence on natural fossil fuels (that are, nonetheless, limited resources) and threats to energy security.

\section{References}

1 Meadows D.H., Meadows D.L., Randers J., Behrens III W.W. The limits to growth: A Report for the Club of Rome's Project on the Predicament of Mankind Paperback, February 18, 1972. - Universe Books, New York, 1974. - 205 p. URL: http://www. donellameadows.org/wp-content/userfiles/Limits-to-Growth-digital-scan-version.pdf

2 Медоуз Д., Рандерс Й., Медоус Д. Пределы роста. 30 лет спустя. - М.: «Академкнига», 2007. - 342 с.

3 Report of the United Nations Conference on the Human Environment. Stockholm, 5-16 June 1972. URL: http://www.undocuments.net/aconf48-14r1.pdf

4 World Conservation Strategy. Living Resource Conservation for Sustainable Development. IUCN-UNEP-WWF, International Union for Conservation of Nature and Natural Resources, Gland, Switzerland, 1980. - 77 p. URL: https://portals.iucn.org/ library/efiles/documents/wcs-004.pdf

5 Report of the World Commission on Environment and Development: Our Common Future, 1987. Annex to document A/42/427 - Development and International Co-operation. - 300 p. URL: http://www.un-documents.net/our-common-future.pdf; URL: Environment http://www.un-documents.net/wced-ocf.htm

6 Rio Declaration on Environment and Development (Annex I). Report of the UN conference on environment and development (Rio de Janeiro, 3-14 June 1992). - United Nations A/CONF.151/26 (Vol. I), 12 August 1992. URL: http://www.un.org/documents/ga/conf151/aconf15126-1annex1.htm; URL:http:/www.unesco.org/education/pdf/RIO_E.PDF.

7 Agenda 21. United Nations Conference on Environment and Development. Rio de Janeiro, Brazil, 3 to 14 June 1992 . - 351 p. URL: https://sustainabledevelopment.un.org/content/documents/Agenda21.pdf

8 IRENA (2017), Renewable capacity statistics 2017, International Renewable Energy Agency (IRENA), Abu Dhabi.

9 Bossel H. Indicators for Sustainable Development: Theory, Method, Applications. A report to the Balaton Group. / International Institute for Sustainable Development. Canada, 1999. - 124 p.

10 Daly H.E. The Steady-State Economy: Toward a Political Economy of Biophysical Equilibrium and Moral Growth. Toward a steady-state economy. - San Francisco, Calif.: Freeman, 1973. - Pp. 149-174

11 Brown L. Building a Sustainable Society / Worldwatch Inst., Washington, D.C. - 1981. - P.440

12 Sachs J. Sustainable Development Economics //article available at URL:https://www.project-syndicate.org/commentary/ promote-sustainable-development-economics-by-jeffrey-d-sachs-2014-11

13 Урсул А.Д., Урсул Т.А. Устойчивое развитие и безопасность. - М., 2013. - 515 р.

14 Сырлыбаева Б. Устойчивое развитие: проблемы определения и реализации // КИСИ при Президенте PK. URL: http:// kisi.kz/ru/categories/ekonomika-i-energetika/posts/ustoychivoe-razvitie-problemy-opredeleniya-i-realizacii (дата обращения: 09.03.2010)

15 Gubaidullina M., Kargina A. Theoretical analysis of the energy efficiency policy concept: Germany and Japan's experience to Kazakhstan // Вестник КазНУ. Серия МО и МП. - 2015. № 4 (72). - С. 76-84

16 Johannesburg Declaration on Sustainable Development/A/CONF.199/20/World Summit on Sustainable Development, 4 September 2002. URL: http://www.un-documents.net/jburgdec.htm

17. Transforming Our World: The 2030 Agenda for Sustainable Development 2015. UN/A/Res/70/1. - 41 p. URL: https://sustainabledevelopment.un.org/content/documents/21252030\%20Agenda\%20for\%20Sustainable\%20Development $\% 20$ web.pdf

18 Закон Республики Казахстан от 4 июля 2009 года № 165 - IV “О поддержке использования возобновляемых источников энергии". URL: https://online.zakon.kz/Document/?doc_id=30445263

19 BP Statistical Review of World Energy 2016. URL: bp.com/statisticalreview

20 Nadirov N.K., Nekrasov V.G., Kenzhebekova K.N. Возобновляемые источники энергии в решении продовольственной проблемы // International Scientific-technical journal. Herald to National Engineering Academy of the Republic of Kazakhstan, 2014. - pp. 80-85

21 Дорошин Г.А. Перспективы использования ветроэнергетики в Казахстане. Проект ПРООН и Правительства РК «Казахстан - инициатива развития рынка ветроэнергетики». Доклад. Алматы, 2006.-15 с.

22 Information-Analytical Magazine Kazenergy, 2016. - N3 (76). P. 19-28

23 Обзор ЮНЕСКО - 2010. Положение дел по использованию возобновляемых источников энергии в Центральной Азии. Алматы, 2010. - 140 c.

24 Strategic Development Plan of the Republic of Kazakhstan until 2020 year: Decree of the President of Republic of Kazakhstan \#922 from February 1, 2010. URL: http://ru.government.kz/docs 
25 «Об утверждении Плана размещения объектов по использованию возобновляемых источников энергии». Приказ Министерства Энергетики Республики Казахстан № 68 от 24 февраля 2017 г.

26 «Об утверждении Плана мероприятий по развитию альтернативной и возобновляемой энергетики в Казахстане на 2013-2020 годы». Постановление Правительства Республики Казахстан № 43 от 25 января 2013 г.

27 Kazakhstan and Kyrgyzstan: Opportunities for Renewable Energy Development/Joint UNDP/World Bank Energy System Management Assistance Programe, Washington, 1997. - 128 p.

28 О программе развития гидроэнергетики на 2016-2020 годы. Постановление Кабинета Министров Республики Узбекистан, 16 ноября 2015 г., № 331. URL: http://www.lex.uz

29 Закон Туркменистана об электроэнергетике, 16 августа 2014 г. http://www.turkmenistan.gov.tm

30 Pendzhiev A.M. Prospects for Green Economy in Turkmenistan // Economic Analysis: Theory and Practice. - 2015. N 38. - S. 14-24. URL: http://www.fin-izdat.ru/journal/analiz/

31 Национальная стратегия Туркменистана по изменению климата, 17 июня 2012. URL: http://tm.one.un.org/content/ dam/unct/turkmenistan/docs/Publications/NATIONAL\%20CLIMATE\%20CHANGE\%20STRATEGY\%20OF\%20TURMENISTAN ru.pdf (дата обращения 2 мая 2016)

$32^{-}$Ban Ki Moon No "Plan B" for climate action as no "Planet B", UN Radio/Daniel Dickinson, 21.09.2014. URL: http://www. unmultimedia.org/radio/english/2014/09/no-plan-b-for-climate-action-as-no-planet-b/\#.Wmk3O7x196o

\section{References}

1 Meadows D.H., Meadows D.L., Randers J., Behrens III W.W. The limits to growth: A Report for the Club of Rome's Project on the Predicament of Mankind Paperback, February 18, 1972. - Universe Books, New York, 1974. - 205 p. URL: http://www.donellameadows.org/wp-content/userfiles/Limits-to-Growth-digital-scan-version.pdf

2 Medouz D., Randers Y., Medous D. Predely rosta. 30 let spustya. [Limits of growth. 30 years later] - M.: «Akademkniga», 2007. $-342 \mathrm{~s}$.

3 Report of the United Nations Conference on the Human Environment. Stockholm, 5-16 June 1972. URL: http://www.undocuments.net/aconf48-14r1.pdf

4 World Conservation Strategy. Living Resource Conservation for Sustainable Development. IUCN-UNEP-WWF, International Union for Conservation of Nature and Natural Resources, Gland, Switzerland, 1980. - 77 p. URL: https://portals.iucn.org/ library/efiles/documents/wcs-004.pdf

5 Report of the World Commission on Environment and Development: Our Common Future, 1987. Annex to document A/42/427 - Development and International Co-operation. - 300 p. URL: http://www.un-documents.net/our-common-future.pdf; URL: Environment http://www.un-documents.net/wced-ocf.htm

6 Rio Declaration on Environment and Development (Annex I). Report of the UN conference on environment and development (Rio de Janeiro, 3-14 June 1992). - United Nations A/CONF.151/26 (Vol. I), 12 August 1992. URL: http://www.un.org/documents/ga/conf151/aconf15126-1annex1.htm; URL:http:/www.unesco.org/education/pdf/RIO_E.PDF.

7 Agenda 21. United Nations Conference on Environment and Development. Rio de Janeiro, Brazil, 3 to 14 June 1992. - 351 p. URL: https://sustainabledevelopment.un.org/content/documents/Agenda21.pdf

8 IRENA (2017), Renewable capacity statistics 2017, International Renewable Energy Agency (IRENA), Abu Dhabi.

9 Bossel H. Indicators for Sustainable Development: Theory, Method, Applications. A report to the Balaton Group. / International Institute for Sustainable Development. Canada, 1999. - 124 p.

10 Daly H.E. The Steady-State Economy: Toward a Political Economy of Biophysical Equilibrium and Moral Growth. Toward a steady-state economy. - San Francisco, Calif.: Freeman, 1973. - Pp. 149-174

11 Brown L. Building a Sustainable Society / Worldwatch Inst., Washington, D.C. - 1981. - P.440

12 Sachs J. Sustainable Development Economics //article available at URL:https://www.project-syndicate.org/commentary/ promote-sustainable-development-economics-by-jeffrey-d-sachs-2014-11

13 Ursul A.D., Ursul T.A. Ustoychivoye razvitiye i bezopasnost'. [Sustainable development and security]. - M., 2013. - 515 s.

14 Syrlybayeva B. Ustoychivoye razvitiye: problemy opredeleniya i realizatsii [Sustainable development: problems of identification and implementation] // KISI pri Prezidente RK. URL: http://kisi.kz/ru/categories/ekonomika-i-energetika/posts/ustoychivoerazvitie-problemy-opredeleniya-i-realizacii (дата обращения: 09.03.2010)

15 Gubaidullina M., Kargina A. Theoretical analysis of the energy efficiency policy concept: Germany and Japan's experience to Kazakhstan // Вестник КазНУ. Серия МО и МП. - 2015. № 4 (72). - С. 76-84

16 Johannesburg Declaration on Sustainable Development/A/CONF.199/20/World Summit on Sustainable Development, 4 September 2002. URL: http://www.un-documents.net/jburgdec.htm

17 Transforming Our World: The 2030 Agenda for Sustainable Development 2015. UN/A/Res/70/1. - 41 p. URL: https://sustainabledevelopment.un.org/content/documents/21252030\%20Agenda\%20for\%20Sustainable\%20Development \%20web.pdf

18 Zakon Respubliki Kazakhstan ot 4 iyulya 2009 goda № 165 - IV “O podderzhke ispol'zovaniya vozobnovlyayemykh istochnikov energii”. [Law of the Republic of Kazakhstan No. 165 - IV of July 4, 2009 “On Support for the Use of Renewable Energy Sources"]. URL: https://online.zakon.kz/Document/?doc id=30445263

19 BP Statistical Review of World Energy 2016. URL: bp.com/statisticalreview

20 Nadirov N.K., Nekrasov V.G., Kenzhebekova K.N. Vozobnovlyayemyye istochniki energii v reshenii prodovol'stvennoy problemy [Renewable energy sources in solving the food problem], International Scientific-technical journal. Herald to National Engineering Academy of the Republic of Kazakhstan, - 2014. - PP. 80-85 
21 Doroshin G.A. Perspektivy ispol'zovaniya vetroenergetiki v Kazakhstane. [Prospects for using wind energy in Kazakhstan] Proyekt PROON i Pravitel'stva RK «Kazakhstan - initsiativa razvitiya rynka vetroenergetiki». Doklad. Almaty, 2006.-15 s.

22 Information-Analytical Magazine Kazenergy, 2016. - N3 (76). P. 19-28

23 Obzor YUNESKO - 2010. [UNESCO Overview 2010] Polozheniye del po ispol'zovaniyu vozobnovlyayemykh istochnikov energii v Tsentral'noy Azii. Almaty, 2010. - 140 s.

24 Strategic Development Plan of the Republic of Kazakhstan until 2020 year: Decree of the President of Republic of Kazakhstan \#922 from February 1, 2010. URL: http://ru.government.kz/docs

25 «Ob utverzhdenii Plana razmeshcheniya obyektov po ispol'zovaniyu vozobnovlyayemykh istochnikov energii». [“On Approval of the Plan for Placing Objects for the Use of Renewable Energy Sources”] Prikaz Ministerstva Energetiki Respubliki Kazakhstan № 68 ot 24 fevralya $2017 \mathrm{~g}$.

$26 « \mathrm{Ob}$ utverzhdenii Plana meropriyatiy po razvitiyu alternativnoy i vozobnovlyayemoy energetiki v Kazakhstane na 20132020 gody». ["On approval of the Action Plan for the Development of Alternative and Renewable Energy in Kazakhstan for 20132020”] Postanovleniye Pravitelstva Respubliki Kazakhstan № 43 ot 25 yanvarya 2013 g.

27 Kazakhstan and Kyrgyzstan: Opportunities for Renewable Energy Development/Joint UNDP/World Bank Energy System Management Assistance Programe, Washington, 1997. - 128 p.

28 O programme razvitiya gidroenergetiki na 2016-2020 gody. [On the program of hydropower development for 2016-2020] Postanovleniye Kabineta Ministrov Respubliki Uzbekistan, 16 noyabrya 2015 g., № 331. URL: http://www.lex.uz

29 Zakon Turkmenistana ob elektroenergetike, 16 avgusta 2014 g. [The Law of Turkmenistan on Electric Power Industry] http://www.turkmenistan.gov.tm

30 Pendzhiev A.M. Prospects for Green Economy in Turkmenistan // Economic Analysis: Theory and Practice. - 2015. N 38. - S. 14-24. URL: HTTP://WwW.FIN-IZDAT.RU/JOURNAL/ANALIZ/

31 Natsional'naya strategiya Turkmenistana po izmeneniyu klimata, 17 iyunya 2012. [National Strategy of Turkmenistan on Climate Change]. URL: http://tm.one.un.org/content/dam/unct/turkmenistan/docs/Publications/NATIONAL\%20CLIMATE\%20 CHANGE\%20STRATEGY\%20OF\%20TURMENISTAN_ru.pdf (дата обращения 2 мая 2016)

32 Ban Ki Moon No "Plan B" for climate action as no "Planet B", UN Radio/Daniel Dickinson, 21.09.2014. URL: http://www. unmultimedia.org/radio/english/2014/09/no-plan-b-for-climate-action-as-no-planet-b/\#.Wmk3O7x196o 